M. Omalinus n. sp.--Body beneath piceous. Head flat above, coarsely punctured, orange-yellow, piceous behind the eyes. Antennæ piceous, four or five basal joints pale. Thorax oval, narrowed in front, a little longer than wide, apex truncate, base feebly areuate, hind angles rounded, dise convex, coarsely and moderately densely punctured, surface orange-yellow sometimes with a median piceous stripe. Elytra coarsely punctured, the punctures gradually finer to apex, surface finely pubescent, color orange-yellow with a common sutural piceous stripe broader at either end, not attaining the apex, sides posteriorly piceous, this color sometimes extending and joining the sutural stripe, forming an anchor. Legs pale yellow. Length .14-.16 inch; $3.5-4 \mathrm{~mm}$. (Pl. VI, fig. 17).

In the male the last ventral segment is feebly emarginate, and entirely piceous in color. In the female arcuate and tipped yellow.

Occurs in western Kansas, collected by Dr. H. A. Brous.

In the accompanying figure the head is represented fully extended. In nature it is deflexed and inserted nearly as far as the eyes. The first glance at the species recalls some of the forms of Omalini (Trigonodemus), hence the specific name.

\title{
Synopsis of the species of the tribe LEBIINI.
}

BY GEORGE H. HORN, M. D.

During the past few years Baron Chaudoir has excited an interest in the truncatipenne series of Carabidæ by his numerous monographic publications, which show a conscientious and profound study of the genera and species of this group. While I have been able to follow him satisfactorily in all the minor details of his work, I have utterly failed to see in his larger subdivisions any evidence of a systematic treatment of the subject.

It will be evident to any one studying Chaudoir's essays on the truncatipenne series that the ligula and paraglossæ play an important part in the diagnoses of the divisions whether called tribes or groups. Thinking that the key to the system might be found by a careful study of these organs, dissections were prepared and drawings made of the parts, for comparison, and the conclusion was forced upon me, as it will be on any one who will adopt the same course, that the mouth organs are of very little value in defining groups higher than genera and when used at all must be used with extreme caution.

With the desire of doing full justice to the subject dissections were made of all accessible genera many of which have been published in the preceding volume. The further the dissections were made the more evident it became that the ligula must be discarded as the basis 
of any system of subdivision of the Carabidæ. Knowing then that the publication of the present paper in the form originally intended would carry with it a very decided expression of the above opinion, I felt that greater weight would attach to that opinion if some other system were presented at the same time. This essay became a secondary matter and the Classification of the Carabidæ as presented in the preceding volume was allowed precedence.

The synoptic table of the genera will not be repeated here, nor will I include Lebia, as nothing of importance has been added since my paper published several years ago.

The descriptions of the species are for the most part short, several of the more troublesome genera only have received greater attention in their details.

\section{TETRA GONOD ERUS Dej.}

This genus is a centre around which are grouped others having in common a form of inner maxillary lobe which I have illustrated in a series of dissections of Carabide mouth parts, (Trans. Am. Ent. Soc. ix, pl. viii, fig. 80). The tibial spurs of the middle and posterior legs are also long and slender and their margins very finely serrulate. The terminal spur of the anterior tibia is more obviously serrulate than the others.

The tribe Tetragonoderidæ as suggested by Chaudoir, (Bull. Mosc. 1876), contains five genera three of which are due to him. Cyclosomus Latr. which belongs here has a decided resemblance to Omophron, and has very oddly place by various authors from an incorrect appreciation of its true relationship which Chaudoir first made known.

Among the genera dismembered from Tetragonoderus is Peronoscelis Chd., which is said to differ from the former by the ligula not margined in front by the extension of the paraglossæ. In the dissection above quoted the ligula and paraglossæ have been drawn exactly as I have observed them and there does not appear to be any extension of membrane in front of the ligula, an appearance of this kind may, however, be produced by disarranging the focus of the microscope and an optical illusion is the result. From the failure of this character there may be considerable doubt of the value of the genus.

In the diagnosis of the two genera will be found the following expressions :

Tetragonoderus $* * *$ unguiculi tenues, acuti, subtus obsoletissime basi, interdum evidentius, denticulati.

Peronoscelis * * * unguiculi simplices, aut obsoletissime basi denticulati.

These extracts are introduced because certain of our species have 
denticulate claws while two have them absolutely simple, and Chaudoir has already supposed that one of the latter may be a Peronosolis although the species was unknown to him in nature.

Tetragonoderus is represented in our fauna by four species which may be arranged in the following manner:

Claws serrate, (Tetragononerus).

Prosternum margined at tip. Elytra in great part piceous. Legs and outer joints of antennæ piceous

intersectus Germ.

Prosternum not margined at tip. Elytra in great part testaceous. Legs and antennæ testaceous.

fasciatus Hald.

Claws simple, no trace of serration, (PERonoscelis?).

Prosternum slightly protuberant, margined at tip. Elytra broadly oval, the dorsal punctures distinct. Eyes convex.

Iatipennis Lec.

Prosternum obtuse, not margined. Elytra oblong-oval, the dorsal punctures indistinct. Eyes not prominent....

pallidus Horn.

T. intersectus Germ. - Piceous, upper surface somewhat bronzed. Antennæ with two basal joints pale. Head smooth. Thorax nearly twice as wide as long, base and apex equal, sides areuate, slightly sinuate posteriorly, hind angles distinct not prominent, dise smooth, median line distinctly impressed but attaining neither the apex nor base. Elytra oval slightly oblong, finely striate, intervals slightly convex, dorsal punctures distinct, situated on the third interval, the anterior somewhat in front of middle near the third stria, the posterior one-fourth from apex near the second stria; color piceous with bronze surface lustre, with a pale space on the intervals $5-6-7$ near the base, one in interrupted sinuous band at apical third testaceous. Prosternum margined at tip. Legs piceo-testaceous. Claws serrate. Length .20 inch; $5 \mathrm{~mm}$.

Male.-The anterior tarsi have three joints moderately dilated and slightly squamulose beneath, the middle tarsi with joints $2-4$ more narrowly dilated. The last ventral segment is acutely notehed at middle posteriorly and on each side one setigerous puncture.

Femule.-Tarsi slender. Anal segment entire and with two setæ on each side.

Chaudoir places this species in a series in which the prosternum is not margined. The resemblance of this insect to a Bembidium of the Notaphus group is certainly remarkable and it is usually found in that vicinity in amateur collections.

Occurs in the States bordering the Gulf.

T. fasciatus Hald.-Piceous, slightly bronzed, antennæ and legs testaceous, elytra fasciate with testaceous. Thorax similar in form to intersectus but less broad and with the sides less arcuate in front. Elytra also more oval, more deeply striate and with the intervals distinctly convex, dorsal punctures as in intersectus ; the color usually in great part testaceous with a semicircular space around the scutellum, a broad sinuous band with irregular edges at middle, and the apical fourth piceous. Prosternum obtuse, not distinctly margined at tip. Claws serrate. Length .18 inch; $4.5 \mathrm{~mm}$.

The sexual characters are as in intersectus.

This species has a far wider distribution than the preceding, occuring 
from Michigan and New York to Louisiana and Texas, extending to Arizona and the Peninsula of California. The more northern specimens are more shining and smaller with the elytra always paler. In the Texas region the specimens are somewhat less shining with darker color.

T. Iatipennis Lec.-Head piceous, surface bronzed, front with a slight arcuate impression each side, the anterior supra-orbital puncture unusually deep. Eyes rather prominent. Antennæ testaceous. Thorax colored as the head, less than twice as wide as long, apex and base equal, margin slightly reflexed, sides arcuate in front, rather strongly sinuate posteriorly, hind angles acute but not prominent, apical areuate impression distinct, in front of which the surface is longitudinally wrinkled, median impression moderately deep, on each side of dise a punctiform impression, basal margin longitudinally wrinkled. Elytra broadly oval, very little longer than wide, striate, the striæ indistinctly punctured, intervals slightly convex, dorsal punctures as in intersectus but each one situated more anteriorly ; color yellowish testaceous with an irregular undulating fascia at middle composed of small piceous spots, the apex for a short distance piceous. Body beneath piceo-testaceous. Legs testaceous. Prosternum slightly protuberant at tip and distinetly margined. Claws simple. Length .20-.22 inch; $5-5.5 \mathrm{~mm}$.

Male.-The anterior tarsi have three joints very distinctly dilated and squamulose beneath, the middle tarsi narrowly dilated with joints $2-4$ squamulose beneath, the first joint only at tip. The anal segment is feebly emarginate at middle and the margin on each side has but one setigerous puncture.

Female.-The tarsi are not dilated. The anal segment entire and with one seta each side as in the male.

It may be observed in this species that the spurs of the tibiæ are less distinctly serrulate than in the two preceding species, the anterior tibial spur especially so. The general appearance of this species is that of a broad fasciatus.

There seems very little doubt in my mind that Chaudoir is correct in merely guessing that this species should be referred to Peronoscelis. It should probably be placed near undatus and mexicanus,

Occurs in Texas.

T. pallidus Horn.-Pale rufo-testaceous, subopaque. Head impunctate, without impressions, eyes not prominent. Antennæ testaceous. Thorax less than twice as wide as long, sides moderately arcuate in front, oblique and very slightly sinuate behind, hind angles rectangular, not prominent, dise with a finely impressed median line and without lateral foveæ. Elytra oblong-oval, finely striate, striæ not punctured, intervals nearly flat, dorsal punctures not evident. Body beneath smooth, prosternum obtuse at tip, not margined. Claws simple. Length $.18-.20$ inch ; $4.5-5 \mathrm{~mm}$.

Male.-Sexual characters as in latipennis.

Femalc.-As in latipennis.

In this species the mentum tooth is broader and less acute than in those which precede.

I have seen but two specimens of this species, one $q$ from the southern district of California, the other from Camp Grant, Arizona.

TRANS. AMER. ENT. SOC. $X$.

AUGUST, 1882. 


\section{N EM O'TA RSUS Lec.}

This genus contains but one species resembling at first sight some of the varieties of Lebia scapularis. The head is rather suddenly narrowed behind the large eyes and the neck is narrow. The thorax is broadest at base which is arcuately truncate, the lateral margin gradually broader from apex to base. Color yellowish testaceous, elytra piceous with an oval spot near the base, and the apex testaceous.

The tibial spurs are long and slender (equalling very nearly the first tarsal joint), their margins not serrulate. The tarsi are slender and long, the first joint equalling the next two, fourth joint simple. Ungues with long pectination.

One species occurs in our fauna.

N. elegans Lec.-Length .20-.22 inch; $5-5.5 \mathrm{~mm}$.

Male--Anterior tarsi feebly dilated, the first three joints finely biseriately squamulose beneath. Middle tarsi slender. Anal segment with one seta each side.

Female.-Tarsi slender. Anal segment bisetose.

\section{LEBIA Latr.}

Since the revision of our native species published by me (Trans. Am. Ent. Soc. iv, p. 130), but one species has been described, (L. rhodopus Schwarz, Proc. Amer. Philos. Soc. 1878, p. $354=$ viridis Say), and one Mexican species observed in Texas, L. bitæniata Chev. This belongs in our series near pulchella. It is pale rufo-testaceous, antennæ piceous the basal two joints pale, legs piceous, the bases of the femora pale. Elytra violaceous, with a yellow band in front of middle, arcuate to the front on each elytron, and another narrower apical band leaving only the sutural angle violaceous. Length .22 inch; $5.5 \mathrm{~mm}$.

In regard to the other species mentioned in our lists very little need be said.

L. ruficollis Lec. is probably merely a variety of cyanipennis Dej., similar variations in color have been observed in the species of Tecnophilus.

L. frigida Chaud. does not present any characters separating it specifically from fuscata Dej.

L. divisa Lec. which has the elytra blue, the basal third red, head and thorax of same color, should probably be referred to the group known as Lamprias in the European fauna. I have seen three speciméns all of which are females.

The genera into which Chaudoir has divided Lebia seem for the most part not only unnecessary but untenable. In a review of our genera of Carabidæ I have attempted to demonstrate by dissection that all the genera have distinct epilobes developed however in a varying degree, hence any division founded on their supposed absence is untenable. 
The four genera into which our species have been divided may be retained as sub-generic divisions on the following basis:

Anterior tarsi of male somewhat obliquely dilated LOXOPEZA. Anterior tarsi of male not obliquely dilated.

Mentum with a distinet tooth. LEBIA.

Mentum not or merely obtusely toothed.

Head not suddenly constricted behind the eyes

Head suddenly constricted.

Dianchomena.

These differences become so vague that it is not always easy to determine with certainty the generic position of a species.

COPTODERA Dej.

In this genus the ligula proper is rather narrow, bisetose at tip, the paraglossæ membranous, wide, prolonged beyond the tip of the ligula, their apices in contact or even overlapping. The mentum is broadly and rather deeply emarginate without tooth. The terminal joints of the palpi are somewhat fusiform. The labrum is large almost concealing the mandibles. Antennæ with the first three joints and the base of the fourth glabrous. The head is not narrowed behind the eyes. Middle of base of thorax very slightly lobed. Tibial spurs normal in length. Tarsi slender, pubescent above, first joint as long as the next two, fourth feebly emarginate. Ungues pectinate.

One species occurs within our territory.

C. aerata Dej.-Piceous, elytra bluish-green. Length .24-.26 inch; 6-6.5 mm. Male-Anterior tarsi feebly dilated, first three joints biseriately squamulose. Middle tibiæ distinctly emarginate on the inner side near the tip, the tarsi slender. Anal segment bisetose each side.

Female.-Tarsi slender. Middle tibia not emarginate. Anal segment as in the male.

The tibial character above noted is usual in Lebia. The present is the only other instance in which I have observed it.

Occurs in the Middle and Southern States.

\section{PHLAEOXENA Chaud.}

The characters are very nearly those of Coptodera. The ligula is quadrisetose in front, the paraglossæ prolonged and slender at tip. The genus does not seem composed of very homogeneous material as one species is added for want of a better position and our own has no mentum tooth as required by the diagnosis. Almost the entire fourth antennal joint is glabrous.

One species occurs in our fauna.

P. signata Dej. (Coptodera).-Head piceous. Thorax testaceous with a median piceous spot more or less defined. Elytra piceous with an undulating faseia posteriorly, and an irregular dentate band more or less interrupted, broad 
at the lateral margin, behind the base, testaceous. Legs testaceous. Length $.22-.24$ inch ; $5.5-6$ mm.

Male.-Anterior tarsi with three joints slightly dilated and beneath biseriately squamulose. Anal segment with one seta each side.

Female.-Tarsi slender. Anal segment bisetose each side.

Occurs in the Gulf States and the Carolinas.

DIROMIUS Bon.

This genus is typical of a group, called by Chaudoir the Dromiides, which seems very closely related to his Callidides as both groups are defined. In examining the ligula it will be observed that all the genera have that member bordered in front by a membrane which is an extension of the paraglossæ, incomplete however in Metabletus. Dromius makes an exception, there is no membranous border whatever, at least in D. piceus.

In Dromius the palpi are slender, the tarsi slender with the fourth joint not bilobed nor emarginate, the ungues more or less serrate and the mentum without tooth.

In our fauna but two species occur, very dissimilar in their general aspect and almost generically distinct. In Europe the species are moderately numerous and in form other characters supply the missing links in our small series. They are:

Entirely piceous. Thorax broader than long, trapezoidal. Elytra nearly parallel, humeri distinct, body winged. Palpi distinctly pubescent........... piceus Dej. Pale testaceous, head black. Form slender. Thorax a little longer than wide, very narrowly margined. Elytra elongate, gradually broader behind, humeri obliterated, body apterous. Palpi not distinctly pubescent........atriceps Lec.

D. piceus Dej.-Piceous, moderately shining. Head distinctly longitudinally wrinkled above the eyes. Thorax trapezoidal, wider than long, narrower at base, sides moderately areuate and margined. the margin moderately reflexed, hind angles obtuse, median line nearly entire, surface slightly, transversely wrinkled. Elytra oblong, parallel, surface striate, striæ not distinctly punctured, intervals slightly convex, dorsal punctures not evident. Body beneath piceous, smooth. Length .26-.30 inch; $6.5-7.5 \mathrm{~mm}$.

Male.-The anterior tarsi of the male are slightly dilated, the first three joints biseriately lamellate beneath. The anal segment is slightly emarginate at middle and on each side are three setigerous punctures.

Female.-Tarsi slender. Anal segment plurisetose each side.

This species extends from the Atlantic region to the Pacific by the northern line. In the eastern region it does not appear to extend further south than North Carolina.

D. atriceps Lec.-Pale yellowish testaceous, head nearly black. Head smooth. Thorax trapezoidal, as long as wide, slightly narrowed behind, sides feebly arcuate in front and very narrowly margined, hind angles obtuse, median line rather deeply impressed, surface smooth. Elytra broader behind, humeri 
rounded, surface very obsoletely striate at middle, smooth externally. Body beneath smooth, shining. Length .16 inch; $4 \mathrm{~mm}$.

The two specimens I have seen seem to be females, the anal segment is bisetose each side.

The specimen in the cabinet of Dr. LeConte has a transverse dark fascia the anterior border of which is in front of the middle of the elytra and straight, the posterior border is concave so that the fascia is twice as broad at the lateral margin as at the suture.

Occurs in Georgia and Louisiana. Seems to be closely related to D. sigma of Europe.

\section{APRISTUS Chaud.}

A genus composed of small black species differing from all our Dromiide genera by the simple, slender claws. The mentum is toothed, the ligula small, cordiform and quadrisetose in front, completely surrounded by its paraglossæ. The thorax is truncate at base.

The species occuring in our fauna are as follows:

Elytral striæ deeply impressed, those at the sides more feebly. Thorax a little wider than long.

Hind angles of thorax acute, slightly prominent, the lateral margin a little broader and more reflexed posteriorly. Median line of thorax deep and reaching the basal margin. Intervals of elytra rather strongly convex. Surface color nearly always black.

cordicollis Lec.

Hind angles of thorax rectangular not prominent, the lateral margin not wider behind. Median line fine, usually not attaining the basal margin. Intervals moderately convex. Surface bronzed....

subsulcatus Dej.

Elytral striæ feeble, those at the sides nearly obsolete. Thorax about one-fourth wider than long.

Hind angles of thorax rectangular not prominent, margin not wider behind. Median line deeply impressed at middle and very faintly reaching the basal margin. Color slightly bronzed.....

Iaticollis Lec.

As the essential characters of the three species are rather fully given in the table the following short notes will supply what is considered necessary.

A. Cordicollis Lec.-This species is larger than subsulcatus, the elytra flatter and the intervals decidedly more convex. The surface color is black with a slight tinge of blue. Length .14-.16 inch; $3.5-4 \mathrm{~mm}$.

Male.-Three joints of anterior tarsi distinctly dilated and densely biseriately squamulose beneath. Anal segment with one seta each side.

Female-Tarsi slender. Anal segment with one seta each side.

Occurs in the Middle States and Canada.

A. Subsuleatus Dej.-The surface color is piceous rather than black with a tendency in the elytra to become brown. The thorax has the sides less arcuate in front, less sinuate behind and is consequently less cordiform than in the preceding species. Length .12-.14 inch ; $3-3.5 \mathrm{~mm}$.

Occurs from Canada to Texas and New Mexico. 
A. laticollis Lec.-The surface is slightly bronzed but much more shining than in either of those which precede. The thorax is rather wider, the striæ less deep and those at the side almost entirely obliterated. Length .12 inch; $3 \mathrm{~mm}$.

Occurs in Oregon, California and Arizona.

\section{BLECH R US Motseh.}

This genus is composed of a small number of black shining species differing from the allied genera either by the slightly lobed base of thorax, the mentum not toothed or the claws serrate. The ligula proper is small and bisetose at tip, the paraglossæ rather wide and completely surrounding the ligula. In examining the illustrations of the mouth parts (Trans. Am. Ent. Soc. ix, pl. viii, figs. 86, 87, 88, 89, 90), it will be observed that Blechrus and Axinopalpus have the ligula bisetose in front, Apristus and Metabletus quadrisetose and Dromius sexsetose.

The species of Blechrus are as follows:

Thorax very distinctly wider than long, broadest about one-third from apex.

Elytra faintly substriate at middle....

nigrinus Mann.

Thorax not wider than long, widest immediately behind the apex.

Elytra almost smooth.

Elytra longer than head and thorax, sides nearly parallel.......Iucidus Lec.

Elytra not longer, sides distinctly arcuate............................. pusio Lee.

B. nigrinus Mann. - Form moderately elongate, depressed, black, shining. Head microscopically alutaceous. Thorax about one-fourth wider than long, sides moderately arcuate in front, slightly sinuate posteriorly, the hind angles rectangular, dise moderately convex, the median line deeply impressed but not entire, the surface very finely transversely strigose. Elytra oblong, nearly parallel, one-third longer than the head and thorax, dise obsoletely striate near the suture, smooth at the sides. Body beneath smooth shining. Legs black. Length .12.14 inch; $3-3.5 \mathrm{~mm}$.

Male.-Anterior tarsi with three joints feebly dilated, indistinetly lamellate beneath. Anal segment with one puneture each side.

Female. Tarsi slender, anal segment with one puncture each side.

This species has a distribution from New York to California by the northern line through Canada, the larger specimens occurring in Vancouver. It will be observed in many specimens that, owing to the thinness of the elytra and their disposition to curl, the form is apparently more elongate. From a comparison under the microscope I can see no differences between the forms from California and those from Lake Superior.

B. Iucidus Lec.-Form and color of nigrinus, differing only as follows: Thorax as long as wide, widest immediately behind the apical angles, hind angles small not prominent. Elytra parallel, nearly without any traces of striæ, the surface microscopically transversely strigose. Length .10--.12 inch; $2.5-3 \mathrm{~mm}$.

Sexual characters as in nigrinus.

Occurs in Kansas, Nevada, Oregon and California. 
B. pusio Lec.-Smaller than lucidus with the thorax more narrowed at base and the hind angles less distinct. The elytra are not longer than the head and thorax, the sides distinctly arcuate. The median line of thorax is also much less impressed. Length .08 inch; $2 \mathrm{~mm}$.

This is the smallest member of the truncatipenne series in our fauna.

Occurs from Ohio to Texas.

ME'TA B LE'TUS Schmidt-Goebel.

This genus contains in our fauna but one species. The thorax is slightly lobed at base, the $\cdot$ mentum with a small emarginate topth, the claws serrate. The ligula is moderately prominent, elongate-oval, with five short setæ in front and four at the tip, the intermediate two short the outer two long. The paraglossæ are broad, a little longer than the ligula but closely united with it, obtuse at tip and not passing in front of the ligula.

M. americanus Dej.-Black, shining, with an extremely faint æneous tinge. Head smooth, shining. Thorax a little less than twice as wide as long, sides areuate in front, slightly sinuate posteriorly, hind angles distinct, not prominent, margin very narrow, dise slightly convex. median line rather deeply impressed, not entire, surface smooth, shining, slightly opaque along the base. Elytra oval, scarcely wider posteriorly, apex distinctly truncate, disc very vaguely substriate, two dorsal punctures very faint. Body beneath almost entirely smooth. Length .10-.12 inch; $2.5-3 \mathrm{~mm}$.

Male.-Anterior tarsi with three joints moderately dilated and feebly biseriately lamellate beneath. Anal segment entire with one seta each side.

Female.-Tarsi slender. Anal segment as in male.

This species bears considerable resemblance to Blechrus nigrinus but the generic characters readily distinguish it. I do not find that M. borealis Zimm. differs essentially from americanus.

This insect is found from Vermont to British Columbia and northward to Hudson's Bay Territory.

\section{AXINOPALPUS Lec.}

Mentum emarginate, distinctly toothed. Ligula (proper) triangular, bisetose at apex, the paraglossæ narrow and bordering it in front, the palpi rather thick the last joint oval subsecuriform, the maxillary palpi slender and long, the terminal joint cylindrical and acutely prolonged at tip. Thorax truncate at base. Tarsal claws distinctly serrate in biplagiatus or very indistinctly in fusciceps.

It will be observed that this genus differs in many important particulars from each of the Dromiide genera which precede and from all of them collectively by the form of the palpi. The ungues have been called simple in fusciceps but an examination shows the base of each claw to have rarely more than one serration while in. biplagiatus there are two or three. 
Two species occur in our fauna.

Piceous, elytra with an oblique testaceous stripe from the humeri.

biplagiatus Dej.

Testaceous, head piceous. fusciceps Lec.

A. biplagiatus Dej.-Piceous, shining. Antennæ, legs and oblique stripe of elytra pale. Head very finely alutaceous. Thorax less than twice as wide as long, slightly cordate, sides arcuate, sinuate near the hind angles which are rectangular but not prominent, dise slightly convex, median line distinctly. impressed and entire, surface smooth. Elytra flat, oval, a little broader behind, apex truncate, disc obsoletely striate at middle; the oblique pale vitta starts from the humerus toward the suture and extends parallel with the latter beyond the middle. Body beneath smooth, shining. Length .12 inch; $3 \mathrm{~mm}$.

Male.-Anterior tarsi with three joints slightly dilated, feebly lamellate beneath. Anal segment slightly notched at middle, a single seta each side.

Female. -Tarsi slender. Anal segment entire, one seta each side.

I fully agree with Dr. LeConte in uniting californicus with this species. It affords another instance of the transcontinental distribution of a species along our northern border.

Occurs from the New England States to California.

A. fusciceps Lec.-Yellowish testaceous, head piceous or nearly black. Head finely alutaceous. Thorax about one-half wider than long, slightly narrowed at base, sides moderately arcuate, somewhat sinuate in front of the hind angles which are rectangular and slightly prominent, dise moderately convex, median line impressed nearly entire, the subapical and antebasal transverse impressions distinct, surface smooth. Elytra oval, a little wider behind, dise slightly convex, vaguely substriate, more distinctly near the suture. Body beneath smooth, shining. Length .12 inch; $3 \mathrm{~mm}$.

Sexual characters as above.

As biplagiatus follows a complete line of transcontinental distribution so this occurs over a shorter line extending from Texas to southern California, following the line which Dr. LeConte has already noticed for so many species which occur in the Peninsula of California.

TECNOPHILUS Chaud.

The species referred to this genus were in times past placed in Philotecnus until removed by Chaudoir, (Bull. Mose. 1877, i, p. 240). The latter genus is said to be identical with Cymindoidea. In the present essay I will not attempt to determine the value of the new genus created for our species and will merely state that as far as a comparison with our genera is concerned it is undoubtedly valid.

The characters of the genus have already been referred to in the preceding volume of these Transactions and sufficiently detailed figures given of the mouth parts. There is no need, therefore, of repeating here except to call attention to the fact that it is one of the few genera of the tribe in our fauna with simple ungues. 
There are five species recognized by Chaudoir, one of them provisional. In order that the student may be in possession of the data on which Chaudoir bases his recognition of these species the following facts are presented.

T. nigricollis Lec., one specimen presented by Dr. LeConte.

T. Pilatei Chd., one specimen said to be from T'exas.

T. ruficollis Lec., no type from the author; two other specimens which seem to differ a little from the description and cause Chaudoir to suggest provisionally the name

T. glabripennis Chd.

T. croceicollis Mén., not seen at all by Chaudoir.

From the above it will be seen that from four specimens two of which belong to one species, enough has been learned to admit the validity of four species and to suggest the possibility of a fifth.

My own cabinet, with that of Dr. LeConte, contains eighteen specimens. I have examined about half as many more from other cabinets and have become convinced that there is but one species variable principally in color. The study in detail is as follows:

Var. Pilatei Chd.-Head and thorax above and beneath red, also the meso- and metasternum, legs and antennæ. Elytra bright blue or greenish-blue, abdomen piceous. This form has the thorax a little less . arcuate on the sides.

Var. ruficollis Lec.-Head and thorax above and beneath red. Antennæ brownish. Meso- and metasternum at middle reddish at sides piceous, abdomen piceous. Legs piceous, brownish-red at base of femora.

Var. croceicollis Mén.-Colored as in ruficollis except that the head becomes brown deepening in color to piceous. The metasternum entirely piceous. Legs piceous.

Var. Colored as in croceicollis with the thorax becoming gradually browner.

Var. nigricollis Lec.-In this variety the elytra are of a deep violetblue, the change from the brilliant blue observed in Pilatei having progressed gradually from that variety to the present. Here the head and thorax above and beneath and the under side of the body, legs and antennæ are piceous becoming shining black.

Var. glabripennis Chaud.-This name was suggested for two specimens of ruficollis from which the fine pubescence of the elytra had been removed. 
In my opinion but one species exists in our fauna :

T. eroceicollis Ménet.-Length .24-.32 inch; $6-8 \mathrm{~mm}$.

Male.-The anterior tarsi are slightly dilated the first three joints biseriately lamellate beneath. The middle tarsi are scarcely at all dilated and with traces of lamellæ on the second and third joints only. The anal segment has one seta each side.

Female.-Tarsi slender hairy beneath. Anal segment with two setæ each side.

Occurs on the Pacific coast from San Diego to Oregon, thence eastward to Montana, Utah and possibly Texas.

\section{EUPR DC'TUS Solier.}

Mentum emarginate, without tooth, epilobes not prominent. Ligula corneous, cuneiform, truncate and quadrisetose at apex, paraglossæ membranous, prolonged across the front of the ligula and ciliate, palpi with terminal joint somewhat triangular. Maxillary palpi with last joint as in the labial. Labrum transverse, not emarginate in front. Mandibles with distinct scrobe externally. Antennæ with the first three and the base of the fourth joint glabrous. Head gradually narrowed behind the eyes to a neck. Thorax truncate at base, slightly oblique near the hind angles which are slightly reflexed. Tarsi slightly flattened above, somewhat pubescent, the first joint of the posterior not as long as the next three, fourth joint on all the feet deeply bilobed. Ungues pectinate.

Notwithstanding that Chaudoir places Euproctus in the Callidides and Tecnophilus in an uncharacterized group Mimodromiides, there does not seem any valid reason for separating them very remotely.

One species occurs in our fauna.

Eu. trivittatus Lec. (Onota).-Bright rufo-testaceous, elytra with a common sutural vitta expanded slightly at middle and a submarginal band extending along the apex to the suture, piceous. Length .20 inch; $5 \mathrm{~mm}$.

Male.-Anterior tarsi feebly dilated, the first three joints biseriately lamellatepapillose, the fourth pubescent. Anal segment with one seta each side.

Female.-Tarsi pubescent beneath. Anal segment bisetose each side.

Collected by Mr. A. Bolter in Florida, at Fort Capron.

CALLIDAD Dej.

This genus is one of the largest in the truncatipenne series, Chaudoir recognizing very nearly one hundred species after separating a number of genera of very doubtful value.

The species in our fauna, although not numerous, have not escaped division and the two genera are separated by characters which seem to have very feeble value and are as follows:

Callida.-Tarsi with a median groove on the upper side more or less apparent. In the male the anterior tarsi are always, the middle very often dilated, the joints beneath biseriately lamellate-papillose, in the middle tarsi the lamellæ are always wanting on the first joint, and sometimes on all the joints.

Spongoloba.-Tarsi neither sulcate nor impressed. In the male 
the first three joints of the anterior tarsi are lamellate-papillose, the middle tarsi with the first joint, sometimes the second also biseriately lamellate, third joint spongy.

Chaudoir further adds concerning the species of the latter genus, "These species which seem to me should not remain in the genus Callida for the reasons above given and because their facies. is quite different, appear to make the transition to the genus Philophyga, of which they have somewhat the form, being however more elongated."

It needs only to be stated that $C$. decora is for Chaudoir a Callida and C.punctata a Spongoloba to convince the majority of American students that any great difference of facies does not exist.

Our species are not numerous and may be separated in the following manner :

Upper side of tarsi flattened and more or less distinctly sulcate or impressed.

Body above uniformly colored.

Color piceous or castaneous, feebly striate................. platynoides Horn.

Piceous, elytra with slight cupreous tinge ...................planulata Lee.

Bright blue or green...........................................viridipennis Say.

Body above bicolored; thorax red, elytra blue or green...............decora Fab.

Upper side of tarsi convex, not sulcate or impressed.

Body above bicolored; thorax red, elytra blue or green...........punctata Lec.

Body bright blue or green.

Elytra distinctly longer than the head and thorax, their surface moderately striate with slightly convex intervals............................fulgida Dej.

Elytra not longer than head and thorax, their surface very finely striate with flat intervals................................................. purpurea Say.

In addition to the above $C$. rubricollis Dej., a Cuban species is said by Chaudoir to occur in our fauna. We have never seen any native specimens.

C. platynoides n. sp.-Form moderately elongate, piceo-testaceous or castaneous, head and thorax somewhat paler than the elytra, shining without trace of metallic surface lustre. Head very sparsely punctulate, front on each side impressed, exteriorly to which the surface is longitudinally wrinkled. Antennæ brownish. Thorax as broad as long, widest in front of middle, sides arcuate in front, feebly sinuate posteriorly the angles rectangular, lateral margin rather wide and slightly reflexed, disc slightly convex, median line distinctly impressed, surface feebly transversely wrinkled and with few punctures along the apical margin, the sides and median line. Elytra oblong, subparallel, striæ finely impressed, indistinctly punctulate, intervals nearly flat finely sparsely punctulate. Dorsal punctures on the third interval, the anterior slightly in front of the middle, the posterior at apical third. Body beneath nearly smooth, a few punctures at the sides of the metasternum. Length .42-.50 inch; $10.5-12.5 \mathrm{~mm}$.

Male.-Anterior tarsi moderately dilated the first three joints biseriately squamulose beneath, the fourth joint nearly naked. Middle tarsi with first joint hairy, second and third biseriately squamulose, fourth nearly naked. Anal segment with one setigerous puncture each side. 
Female.-The anterior and middle tarsi are nearly as widely dilated as the male, the first three joints hairy beneath, the fourth less hairy. Anal segment each side bipunctate.

This is the largest species in our fauna and the only one without any trace of metallic surface lustre. The general appearance at first sight recalls the bicolor variety of Platynus brunneomarginatus or Pinacodera platicollis. It is probably closely allied to $C$. brunnea Dej., from the vicinity of the City of Mexico, the female is however described as having the tarsi spongy beneath.

Occurs in the mountains east of Visalia, California, also in southwestern Utah.

It is remarkable that California should furnish two brownish species in adjacent genera in which all the other species are more or less metallic.

C. planulata Lec.-Form moderately elongate, piceous, elytra with eupreoviolaceous surface lustre, the sides slightly greenish. Head smooth, front vaguely impressed each side. Antennæ brownish. Thorax about as wide as long, broadest at middle the sides areuate, very slightly sinuate in front of the hind angles which are rectangular, lateral margin slightly reflexed, very narrow in front, gradually wider posteriorly, dise slightly convex, the median line broadly and deeply impressed, surface slightly wrinkled latérally and with a few punctures at apex, along the median line and at the sides. Elytra oblong-oval, rather deeply striate, the striæ very finely punctured, intervals convex and with very few punctures. Dorsal punctures as in the preceding species. Body beneath piceous, shining and nearly smooth. Length .44 inch; $11 \mathrm{~mm}$.

Male.-Unknown.

Female--Anterior tarsi slightly dilated, the first four joints spongy beneath. Middle tarsi less dilated, first joint hairy the next three spongy. Anal segment with four punctures each side.

I have seen but one specimen, that described by Dr. LeConte from the Berlandiere collection the localities of which are not accurately stated. The specimen may have been taken in Mexico or Texas.

Chaudoir (Annales Belg. 1872, p. 120), describes C. metallescens from Vera Cruz, Mexico, which may be identical with planulata.

C. viridipennis Say.-Form elongate, color bright bluish-green, elytra usually margined with cupreous. Antennæ piceous, three basal joints paler. Legs piceous. Vertex smooth, front impressed each side and rugulose. Thorax a little longer than wide, sides very feebly arcuate, widest a little in front of middle, margin narrow, a little wider posteriorly, hind angles rectangular not prominent, dise moderately convex, median line impressed, a little deeper posteriorly, surface very sparsely punctulate and obsoletely wrinkled. Elytra oblong, the sides very feebly arcuate, dise striate, the striæ very finely punctulate, intervals slightly convex, obsoletely sparsely punctulate. Body beneath piceous with slight metallic lustre, surface nearly smooth. Length .36-.40 inch; 9-10 mm.

Male.-Anterior tarsi moderately dilated, the first three joints biseriately lamellate beneath, the fourth joint spongy. Middle tarsi less dilated, similarly clothed. Anal segment with one puncture each side. 
Female.-Anterior and middle tarsi less dilated than in the male, the first three joints pubescent, the fourth somewhat spongy. Anal segment bisetose each side.

Occurs in the Gulf States from Florida to Texas.

C. decora Fab.-Form slender, body beneath bicolored, above, head and thorax green or blue, thorax yellowish-red. Legs yellow, the tips of the femora and tarsi piceous. Antennæ piceous, three or four basal joints testaceous. Head smooth, front areuately impressed each side and slightly rugose. Thorax as broad or a little broader than long, widest in front of middle, sides arcuate in front, slightly sinuate posteriorly, the angles rectangular sometimes slightly prominent, lateral margin narrow, equal from base to apex, narrowly reflexed, disc moderately convex, median line impressed, surface nearly smooth, a few punctures along the apical and lateral margins. Elytra oblong, sides feebly arcuate, striæ very fine and finely punctured, intervals very flat and finely sparsely punctulate, dorsal punctures as in planulata. Body beneath smooth, the head and abdomen piceous, the remainder of the body yellowish-red. Length .28-.34 inch; $7-8.5 \mathrm{~mm}$.

Male.-The first three joints of the anterior tarsi are biseriately lamellate beneath, the fourth somewhat spongy, the middle tarsi with first joint setose, second and third lamellate, fourth spongy. Anal segment bipunctate each side.

Female.-Anterior and middle tarsi more slender than the male and pubescent beneath. Anal segment trisetose each side.

This species closely resembles punctata but has a wider thorax with a more distinct margin. The impressed tarsi will also distinguish the present species.

As synonyms of this species I place cordicollis Putz. described from Mexico and cyanoptera Lec. from Texas, these two are certainly the same and differ from decora merely in having the elytra more blue.

Occurs in the Gulf States and Mexico.

C. punctata Lec.-Form slender, colored as in decora. Head and antennæ as in decora. Thorax not longer than the head, a little longer than wide, widest a little in front of middle, sides arcuate, slightly sinuate posteriorly, the hind angles obtuse, lateral margin extremely narrow, disc convex, median line distinctly impressed, surface transversely wrinkled, a few punctures near the apex. Elytra oblong gradually broader posteriorly, surface finely striate, striæ punctate, intervals flat, obsoletely sparsely punetate. Body beneath and legs as in decora. Length .28-.30 inch; $7-7.5 \mathrm{~mm}$.

Male.-Anterior tarsi dilated, first three joints biseriately squamulose beneath, the fourth nearly naked, middle tarsi less dilated the first joint hairy beneath, second and third squamulose, fourth spongy. Anal segment bisetose each side.

Female.-Tarsi less dilated than in the male, with stiff hairs beneath. Anal segment bipunctate each side.

This species closely resembles decora but the thorax is much narrower and the margin extremely narrow. I see no reason why Chaudoir preferred to compare it with smaragdina (= purpurea).

Occurs in Michigan, Ohio, Louisiana and Kansas.

C. fulgida Dej.-Form moderately elongate, color bright metallic greenishblue. Antennæ piceous, first three joints and the basal half of the fourth testaceous. Head nearly smooth, front with a vague impression each side and slightly 
wrinkled. Thorax a little longer than wide, widest at middle, base a little narrower than apex, sides moderately arcuate, very feebly sinuate in front of the hind angles which are obtuse, almost rounded, margin very narrow, dise slightly convex, median line moderately deeply impressed, surface obsoletely transversely wrinkled, a few obsolete punctures along the apical margin ard sides. Elytra oblong, slightly wider posteriorly, longer than the head and thorax, striæ moderately deep, finely punctulate, intervals slightly convex, sparsely obsoletely punctulate. Body beneath blue, smooth, shining. Length . $32-.40$ inch; $8-10 \mathrm{~mm}$.

Sexual characters as in punctata except that the anal segment of the female is tripunctate.

This species has some resemblance to viridipennis but is more brightly colored, has a more narrowly margined thorax and with the base not impressed above.

Occurs in Georgia and Florida.

C. purpurea Say. -Form more robust, as in Philophuga amana, color deep blue or violet varying to green, moderately shining. Antennæ as in fulgida. Head sparsely punctulate, front vaguely impressed each side and rugulose. Thorax as broad as long, base and apex equal, sides arcuate, a very feeble sinuation in front of the hind angles which are obtuse, margin narrow, a little wider posteriorly, dise moderately convex, median line impressed, surface transversely wrinkled especially near the sides, a few punctures along the apical margin. Elytra oval, slightly oblong, scarcely longer than the head and thorax, a little wider posteriorly, sides moderately arcuate, disc finely striate, striæ punctured, intervals flat or very slightly convex near the base, sparsely obsoletely punctulate. Body beneath smooth, shining. Length .30-.36 inch; $7.5-9 \mathrm{~mm}$.

Sexual eharacters as in fulgida.

For what reason Say's name purpurea has been heretofore applied to a species now referred to the genus Philophuga, I can not understand. In the Trans. Amer. Philos. Soc. 1823, p. 10, Say describes Cymindis purpurea immediately after viridipennis, and of both he says, "penultimate joint of tarsi bilobate," and in comparing the two species says, " in form and magnitude resembles $C$. viridipennis but is more depressed and wider." I think there can be no doubt that this species is the true purpurea. .It greatly resembles Philophuga amœna in external appearance, but the latter has the fourth tarsal joint emarginate and not bilobed.

Occurs in Michigan, Georgia, Missouri and Kansas. The specimens from the latter region are darker blue in color, and I at one time referred to them as a probable new species; they do not differ otherwise.

\section{PHILOPH UGA Motsch.}

This genus contains those species in our fauna formerly placed in Glycia. It is very closely related to Callida and differs in having the fourth tarsal joint emarginate, not bilobed. An examination of the ligula does not show any reason why Philophuga should be remotely separated 
from Callida. In the dissections which I have made and figured (Trans. Am. Ent. Soc. ix, pl. viii, figs. 93, 94, 95), there will not be found any remarkable differences between these genera and no reason is apparent why Chaudoir should not have included the present genus in his Callidides. It is however treated apart (Bull. Mosc. 1877, i, p. 243), with no suggestions as to its position, being simply compared with Tecnophilus with which it has far less in common than Callida or Plochionus.

The species at present known are distinguished as follows:

Body winged, elytra very little narrowed at base.

Color blue or green.

Elytral striæ fine, not impressed; head and thorax metallic-green, elytra blue or violet.

viridicollis Lec.

Elytral striæ deeply impressed on the disc, finer externally; body above entirely blue or bluish-green.

amoena Lec.

Color castaneous castanea n. sp.

Body apterous, elytra narrowed at base.

Color uniformly bluish or greenish.

viridis Dej.

P. viridicollis Lec.-Body beneath bluish-green, legs black with slight purplish tinge, head and thorax metallic-green, elytra blue. Front each side broadly impressed and punctured, vertex and oceiput very sparsely punctate. Antennæ piceous, three basal joints paler. Thorax not wider than long, very narrowly margined, sides feebly arcuate and gradually narrowing to base, hind angles not prominent, base regularly arcuate; disc moderately convex, median and subapical lines distinctly impressed, surface transversely wrinkled and punctured along the apex, sides and base. Elytra oblong, a little less than twice as long as wide at base, surface finely striate, striæ punctured, more distinctly near the base, more finely and distantly posteriorly, intervals flat, very sparsely punctate. Body beneath smooth, a few punctures at the sides of the pro- and metasterna. Body winged. Length .40 inch; $10 \mathrm{~mm}$.

Male.-The anterior tarsi have four joints very distinctly dilated and biseriately lamellate beneath, the middle tarsi are similar but a little less dilated. The anal segment is entire and with two setigerous punctures each side.

Female.-Tarsi slender. Anal segment with three punctures.

I can not understand by what misconception Chaudoir considers this species purpurea Say, which is a true Callida, nor am I aware that Dr. LeConte has at any time united his amona with the present species. Specimens were sent by me to Chaudoir as stated by him and the only explanation of the error may be found in a possible confusion of the labels.

The correct synonymy will be found at the end of the paper.

Occurs in Texas extending northward to Kansas.

P. amøna Lec.-Body above and beneath uniformly blue or green, more or less metallic, legs black with a tinge of purple. Head oval, front coarsely punctured each side, more sparsely on the vertex and occiput. Antennæ piceous, three basal joints paler. Thorax distinctly wider than long, otherwise similar 
to viridicollis with the rugæ more distinet and the punctures more numerous extending on the disc. Elytra about one-fourth longer than wide, not narrowed at base, surface striate, the striæ moderately impressed on the disc and distinctly punctate, intervals slightly convex and sparsely punctulate. Body winged, beneath smooth sparsely punctate at sides of pro- and metasterna. Length .30.32 inch; $7.5-8 \mathrm{~mm}$.

Male.-Tarsal characters as in viridicollis. Anal segment with a very feeble emargination at middle and bisetose each side.

Female.-As in virndicollis.

In the "List of the Coleoptera of North America," Dr. LeConte places this species as a variety of purpurea Say, which is by Say's description a true Callida. Chaudoir having confused the matter by considering purpurea, viridicollis and amona synonymous, gave a new name to the present species, which any one would recognize as distinct from viridicollis, and called it Horni. It bears a very close resemblance to Callida purpurea Say, but the latter has the bilobed fourth tarsal joint and an obtuse mentum tooth.

This species occurs from Kansas through Utah and Nevada to California.

P. viridis Dej.-Color uniformly blue or green, more or less metallic. Front broadly impressed and punctured each side, vertex smooth, occiput very sparsely punctured. Antennæ piceous, three basal joints pale. Thorax broader than long, somewhat cordiform, sides arcuate in front, distinctly sinuate posteriorly, hind angles subacute, somewhat prominent, sculpture similar to viridicollis but much smoother on the dise. Elytra very little longer than wide posteriorly, narrowed at base, dise with impressed, finely punctured striæ, the intervals flat with rather coarse but irregularly placed punctures. Body apterous, beneath somewhat wrinkled but without punctures. Legs black with slight purple tinge. Length . 30 inch; $7.5 \mathrm{~mm}$.

Male.--Sexual characters of amøa .

Female.-Unknown.

I have never seen but one specimen of this insect collected in Oregon by the late W. M. Gabb. It resembles amona but differs in its more distinctly cordiform thorax, the form of the elytra and the apterous body.

Chaudoir appears to have been more fortunate in obtaining specimens as he mentions variations of color from blue and green to nearly black.

P. castanea n. sp.-Castaneous, moderately shining. Front with a feeble depression each side with few punctures, vertex smooth, occiput very sparsely punctulate. Antennæ piceo-testaceous. Thorax broader than long, somewhat cordate, sides strongly arcuate in front, sinuate posteriorly, hind angles sharply rectangular, dise moderately convex, median line finely impressed, apical line obsolete, surface punctured along the apex base and sides, the latter somewhat wrinkled, middle of dise sparsely punctulate or nearly smooth. Elytra about 
one-half longer than wide, base slightly narrowed, disc with moderately deeply impressed, finely punctured striæ, the intervals slightly convex sparsely punctate. Body winged, beneath smooth. Length .36 $\delta-.42$ inch; $9-10.5 \mathrm{~mm}$.

Male.-Tarsal characters of amcena. Anal segment truncate, on each side a muricately punctured space from which numerous hairs arise.

Femalc.-Tarsi slender. Anal segment with three setæ each side.

This species has very nearly the form of amona, the thorax however more nearly that of viridis. Its color makes it an odd member of the genus, but parallel instances are found in Callida.

The sexual characters of the male in the anal segment are also at variance with the other species, but I have been unable to find any valid reason for separating it from Philophuga.

Two specimens from the high mountains in Kern Co., California.

\section{PLOCIION US Dej.}

Although plainly distinct from Callida, it is by no means an easy matter to sharply define the two genera. Chaudoir relies on the quadrisetose ligula of Plochionus, bisetose in Callida. The structure of the fourth tarsal joint whether bilobed or emarginate does not separate all the Plochioni, but it must be admitted that in Callida the lobes are longer and more divergent.

Chaudoir properly separates the species of Plochionus, forming two sub-genera which seem nearly parallel with the two genera created at the expense of Callida.

Our species are as follows:

Fourth tarsal joint emarginate; tarsi flattened above; ungues with short pectination.

pallens Fab.

Fourth tarsal joint bilobed; tarsi not flattened, more slender; ungues with longer pectination.

Color above uniform, piceous or a little paler.

Rufo-testaceous, elytra bicolored.

Elytra with a submarginal spot and common sutural piceous vitta.

amandus Newm.

Elytra piceous with a narrow margin and large oval discal space rufotestaceous.

dorsalis $n$. $\mathrm{sp}$.

P. pallens Fab.-Piceo-testaceous. Head smooth, a moderately deep impression each side of the front. Thorax broader than long, base wider than apex, sides arcuate in front, obliquely narrowing to the hind angles which are rectangular, lateral margin broad, dise feebly convex, median line entire, surface obsoletely transversely wrinkled. Elytra deeply striate, striæ obsoletely punetulate, intervals slightly convex, sparsely obsoletely punctulate. Body beneath smooth, shining. Length .26-.38 inch; $6.5-9.5 \mathrm{~mm}$.

Male.-Anterior tarsi with four joints moderately dilated, the first three lamellate-papillose beneath, middle tarsi less dilated, with the second and third joints lamellate beneath. Anal segment bisetose each side.

Female.-Tarsi not lamellate. Anal segment as in male. 
In this species, as indicated in the table, the tarsi are flattened above and subsulcate at middle, the fourth joint simply emarginate, the ungues with rather short pectination, almost serrate.

This insect has been diffused by commerce over the entire globe and is found near all the cities of our seaboard visited by foreign vessels.

P. timidus Hald.-Very similar in form and color to pallens. The thorax is rather shorter, the sides more arcuate, the hind angles more sharply rectangular. The tarsi are slender, cylindrical, not flattened nor sulcate above, the ungues with longer pectination. Length .28-.30 inch; $7-7.5 \mathrm{~mm}$.

Male.-Anterior tarsi narrowly dilated, the first three joints biseriately squamulose beneath, middle tarsi less dilated, first joint hairy beneath, the next three squamulose. Anal segment bisetose each side.

Female.-Tarsi slender. Anal segment with three or four setæ each side.

Occurs from Pennsylvania to Texas and California.

P. amandus Newm.-Resembles in form that next deseribed (dorsalis), but is somewhat larger and narrower. It differs more especially in the mode of elytral coloration. There is a common sutural piceous stripe occupying the inner three intervals and a small oval piceous spot near each side margin a little behind the middle. Length .28 inch; $7 \mathrm{~mm}$.

I have seen but one specimen, a female, not differing in sexual characters from dorsalis, taken in Florida.

P. dorsalis n. sp.-Bright rufo-testaceous, elytra piceous with the narrow side margin and large discal space rufo-testaceous. Head sparsely obsoletely punctulate, front each side impressed. Antennæ pale. Thorax transverse, broadest at middle, base broader than apex, sides arcuate in front, oblique behind the middle, hind angles rectangular but not prominent, lateral margin wide broader posteriorly, disc moderately convex, median line entire, surface transversely wrinkled. Elytra striate, striæ very obsoletely punctulate, intervals slightly convex with distant minute punctures. Body beneath and legs bright rufotestaceous, abdomen smooth. Length .26-.28 inch; $6.5-7 \mathrm{~mm}$.

Male.-Anterior tarsi with four joints moderately dilated and biseriately squamulose beneath, middle tarsi less dilated the first joint setose the next three squamulose. Anal segment bisetose each side.

Female.-Tarsi slender. Anal segment with three or four setæ each side.

This species has very closely the form of timidus Hald., but differs in color. The oval rufo-testaceous spot on the elytra extends to the fifth stria on each side and varies very slightly in form in all the specimens I have seen.

Collected by Mr. H. G. Hubbard in Florida.

PINACODERA Schaum.

The species here included were separated by Schaum from Cymindis from which it differs in having the tarsal joints not hairy above, and by the middle tarsi of the male being dilated. The terminal joints of both palpi are similar and not securiform, but more or less truncate at tip. 
In addition to these characters it will be observed that all our species of Pinacodera have well developed wings, in Cymindis the wings are aborted or absent.

Our species are distinguished as follows:

Hind angles of thorax obtuse, not prominent.

Elytral intervals slightly convex in their entire length. Thoracic margin narrow, scarcely translucent.

limbata Dej.

Elytral intervals flat.' Thoracic margin broad and translucent.

Hind angles of thorax distinct, slightly prominent.

platicollis Say.

Margin of thorax broad, not wider at base than apex......punctigera Lec.

Margin of thorax very narrow in front, a little wider at base.

Intervals convex at base, flat posteriorly. Thorax distinctly broader than long.....

semisulcata $n$. sp.

Intervals convex in their entire extent. Thorax not broader than long.

sulcipennis $n$. sp.

In addition to the above number in our fauna Chaudoir has described four from Mexico.

P. limbata Dej.-Piceous, legs, antennæ, humeral spot and sides of elytra paler. Head smooth, slightly wrinkled above the eyes. Thorax one-third wider than long, sides moderately arcuate and somewhat narrowed to base, hind angles very obtuse or rounded, margin rather broad, moderately reflexed and translucent, disc moderately convex, median line finely impressed, surface nearly smooth. Elytra oval stightly oblong, with fine moderately impressed and obsoletely punctulate striæ, the intervals slightly convex with a few fine punctures very sparsely placed, dorsal punctures on the third interval near the third stria; color piceous, with testaceous humeral spot which extends along the outer two marginal intervals to apex. Body beneath piceo-testaceous, smooth. Length .32-.40 inch; $8-10 \mathrm{~mm}$.

Male.-Anterior tarsi with four joints dilated and biseriately lamellate beneath, middle tarsi less dilated, similarly lamellate, anal segment with two punctures each side.

Female.-Tarsi slender. Anal segment as in male.

This species is as a general rule smaller than platicollis, the thorax with a broader and more translucent margin, and has the humeral spot and side margin pale. The hind angle of the thorax is also more rounded

Chaudoir and LeConte mention varieties of this species without the humeral spot but I have not met with such, the specimens in the collection of LeConte referred to fuscata Dej., (which Chaudoir unites with limbata), seem plainly paler forms of platicollis.

Occurs from the Middle States southward.

P. platicollis Say.-Piceous, antennæ and legs testaceous. Head with a few wrinkles above the eyes and with the vertex very sparsely punctulate. Thorax one-third broader than long very little narrowed behind, margin moderate, not translucent, distinctly reflexed, hind angles distinct not rounded, dise slightly 
convex, median line finely impressed, surface often slightly wrinkled and with a few punctures near the hind angles. Elytra oblong, striæ fine and obsoletely punctulate, intervals usually flat and sparsely punctulate, the dorsal punctures as in limbata. Body beneath piceous, smooth. Length .36-.44 inch; $9-11 \mathrm{~mm}$.

Sexual characters as in limbata.

The convexity of the elytral intervals in the preceding species and their flatness in this are not strictly accurate characters for distinguishing the two, as specimens occasionally occur which belong unmistakably to the present species in which the intervals are slightly convex. It seems probable that Planesus fuscicollis Motsch., should be referred to the present rather than the preceding species.

Occurs with the preceding species.

P. punctigera Lec.-Brownish piceous, feebly shining. Head sparsely punctate, a few wrinkles over the eyes. Thorax one-third broader than long, distinctly narrowed at base, hind angles rectangular, margin rather narrow but wider posteriorly and more reflexed, disc slightly convex, median line finely impressed from base to apex, surface obsoletely wrinkled and sparsely punctulate. Elytra oblong-oval, with fine striæ, obsoletely punetulate, the intervals slightly convex near the base, flat posteriorly and sparsely punctulate, dorsal punctures as in limbata. Body beneath smooth and with the legs rufo-piceous. Eength .38$.40 \mathrm{inch} ; 9.5-10 \mathrm{~mm}$.

Sexual characters as in limbata.

This species resembles some of the paler forms of platicollis but has the hind angles of the thorax more distinct and the surface more wrinkled and punctulate.

Occurs near Fort Yuma, California, and in Arizona.

P. suleipennis n. sp.-Piceous, very slightly shining. Head irregularly rugose on the front, vertex sparsely punctate. Antennæ piceous. Thorax about as long as wide, sides moderately arcuate, slightly sinuate posteriorly, hind angles acute slightly prominent, margin narrowly reflexed in front, a little wider posteriorly, disc moderately convex, median line distinctly impressed but not entire, subapical impression distinct, surface nearly smooth. Elytra oblong-oval, rather deeply striate, the striæ not punctured, intervals convex in their entire length and without punctures, dorsal punctures very small, placed as in limbata. Body beneath piceous, smooth. Legs rufo-piceous. Length .40 inch; $10 \mathrm{~mm}$.

Male.-Tarsal characters as in limbata. Anal segment with but one puncture each side.

This species appears related to P. basipunctata Chd. found in Mexico, but seems distinct by the elytral sculpture.

I have seen but one specimen, collected in the Peninsula of California by the late W. M. Gabb.

P. semisulcata n. sp.-Piceous, feebly shining. Head sparsely punctate, slightly wrinkled above the eyes. Antennæ rufo-piceous. Thorax one-third wider than long, sides moderately arcuate, slightly sinuate posteriorly, the hind angles distinct and slightly prominent, margin very narrowly reflexed in front, a little 
wider posteriorly, disc slightly convex, median line distinct but not entire, subapical line obsolete, surface very sparsely punctulate at middle, slightly wrinkled at the sides, more distinetly punctulate at base and apex. Elytra oblong-oval, finely striate, deeper at base, the striæ not distinctly punctured, intervals convex in the basal region, then very flat to the apex, the surface not distinctly punctured. Body beneath piceous, smooth. Legs piceous. Length .44 inch; $11 \mathrm{~mm}$.

Male.-Sexual characters as in sulcipennis.

This species resembles punctigera but has a narrower thoracic margin and with differently sculptured elytra. In the latter respect it resembles basipunctata Chd., which however seems to have a thorax more nearly like our Plochionus.

One specimen from the Peninsula of California, collected by the late W. M. Gabb.

\section{CYMIN DIS Latr.}

This genus originally indicated by Latreille was made by that author, and many who have followed him, a magazine for very dissimilar material, The dismemberment began with Castelman in 1832, and has been continued by Schaum, LeConte and Chaudoir, Pinacodera and Apenes being the result in our fauna. At the time of Chaudoir's "Monographic Essay," (Berl. Zeits. 1873), eighty-eight species were known, of which fourteen belong to our fauna. This latter number must be reduced to ten and from the character of the differences given in the descriptions it seems probable that a proportionate reduction should be made in the exotic species.

Our species make a very homogeneous aggregate, no one being in any way aberrant. All agree in being apterous and are consequently terrestrial in their habits. I am not aware of the existence of any forms among the exotics with wings, this character being entirely overlooked. Apenes and Pinacodera have well developed wings and as far as our fauna is concerned we have this as an additional character separating them from Cymindis.

In our fauna all the species are more or less hairy above, but exotic forms, about twenty-five in number, are entirely glabrous, these are mostly European.

The mode of pectination of the tarsal claws is quite constant, varying very slightly in the greater or less length of the teeth. The tarsal joints are always hairy above, the fourth joint slightly emarginate.

The species known in our fauna are not numerous but are with difficulty separable in tabular form. The following table will assist the student but must not be too strictly interpreted without reference to the descriptions. 
Thorax widely margined, the margin more or less translucent.

Interstrial spaces with confused punctures.

Head and thorax similar in eolor to the elytra, the latter without distinct humeral and lateral paler spaces.

Margin of thorax of moderate extent, very little reflexed and scarcely translucent, with many, usually three or more, setigerous punctures.

laticollis Say.

Margin of thorax wide, translucent, distinetly reflexed, with one or two setigerous punctures.

cribrieollis Dej.

Head and thorax usually paler than the elytra, the latter with distinct humeral spot and lateral margin paler, the surface in fully colored specimens somewhat metallic..

planipennis Lec.

Interstrial spaces with a single row of punctures.....................elegans Lee. Thorax arrowly margined.

Thorax distinctly broader than long, the margin wider than in the following species and with but one setigerous puncture at the side.

unicolor Kby.

Thorax not wider than long, margin extremely narrow, sides with at least two setæ.

Elytra rather flat, intervals densely and comparatively finely punctured and without lustre.

americana Dej.

Elytra normally convex, intervals not densely punctured, the punctures often coarse, surface shining.

Thorax equally punctured, the median line feebly impressed.

Thorax very coarsely punctured, the punctures subconfluent at the sides, margin rarely with translucent edge.

cribrata Lec.

Thorax normally not confluently punctured, sides with distinet but narrow translucent border.

Surface conspicuously pubescent, elytra never with humeral pale space.

pilosa Say.

Surface not conspicuously pubescent, elytra with pale humeral space.

borealis Lec.

Thorax unequally punctured, median line deeply impressed. Elytral intervals with one row of punctures.

neglecta Hald.

C. laticollis Say.-Piceous, moderately shining, elytra often with faint bluish tinge, legs and antennæ rufo-testaceous. Head coarsely and deeply, not densely punctured, middle of front less so. Thorax about one-third wider than long, sides arcuate, slightly sinuate posteriorly, hind angles distinct, not prominent, margin moderate in width, nearly equal from apex to base and slightly reflexed, dise moderately convex, median line distinct but not entire, surface coarsely and deeply punctured, rather sparsely at middle, more densely at the sides and base, with moderately long erect brownish hairs, the margin with usually four punctures bearing longer erect setæ. Elytra oval, uniformly piceous, with semi-erect brownish hairs, those on intervals $3-5-7$ longer, surface rather deeply striate, striæ with coarse punctures, intervals slightly convex, very irregularly biseriately punctulate. Prothorax beneath coarsely and deeply punctate, body and abdomen very sparsely punctate. Length .44-.48 inch; 11-12 mm.

Male.-Anterior tarsi with three joints moderately dilated and biseriately squammuligerous. Anal segment slightly emarginate, trisetose each side.

Female.-Tarsi slender. Anal segment entire, trisetose each side. 
From the collection of Baron Chaudoir I obtained a specimen of the species named villigera, and find no differences between it and his types of laticollis except that the hairs of the surface are better preserved.

Occurs in Colorado, Texas and New Mexico.

C. Cribricollis Dej.-Piceous, legs and antennæ rufous. Head coarsely and deeply punctured, less densely in the middle of the front. Thorax nearly onethird wider than long, base equalling the length, sides arcuate, slightly sinuate in front of the hind. angles which are subacute but not prominent, margin broad, translucent, equal in width from base to apex, moderately reflexed and with a variable number of setigerous punctures, not exceeding three, disc moderately convex, median line distinctly impressed, surface coarsely and deeply punctured, more sparsely at middle but not very densely at the sides. Elytra oval, usually a little broader behind, piceous, very rarely with an indistinct humeral spot and pale margin, moderately deeply striate, the striæ punctured, intervals usually convex and irregularly punctulate. Prothorax beneath coarsely and deeply punctured, metasternum at sides less coarsely punctured, abdomen sparsely punctured. Length .36-.44 inch; $9-11 \mathrm{~mm}$.

Male-Anterior tarsi with three dilated joints biseriately lamellate beneath. Anal segment feebly emarginate at middle and each side bisetose.

Female.-Tarsi slender. Anal segment entire, bisetose each side.

The variations of this species are not very striking, notwithstanding its very wide distribution. In several specimens before me from Maine and New Hampshire, the margin of the thorax is rather wider and more translucent and the edge less arcuate in outline. There is also a more evident paler humeral space and the pale edge of the elytra is quite distinct. These can not be considered a distinct species as it is quite impossible to draw any line with sufficient sharpness between them and the more usual form. As the species approaches the Pacific coast the elytral intervals become somewhat flatter, and the individuals are of an average greater size than those of the more eastern regions, this form might be considered represented by the name abstrusa Lec.

The synonymy of this species is also somewhat confused. That the species here described is cribricollis Dej., there can be no doubt. I fully agree with Dr. LeConte in his determination of marginata Kby., as a synonym, for the following reasons: it is the more common species of the region from which Kirby's material was collected, corresponds closely with the description, and is the only widely margined species known to occur there. Chaudoir considers planipennis Lec. (brevipennis Zimm.), identical with Kirby's, which can not be true from the fact that the former occurs in the Rocky Mountain region and Oregon, not coming east of the Mississippi, moreover Kirby would not have failed to mention the decidedly bluish-green color of the elytra.

Occurs from Newfoundland through the New England States to 
Canada, Montana, Oregon and Vancouver, and southward along the Rocky Mountains to Colorado. I have one specimen from Arizona which I refer to this species.

C. planipennis Lec.-Form rather short, piceous or piceo-testaceous beneath, head and thorax usually paler than the elytra which have a distinctly metallic surface lustre, the humeri and lateral margins testaceous. Head sparsely punctate, the punctures not coarse except over the posterior border of the eyes. Thorax one-third wider than long, narrowed at base, sides arcuate, sinuate posteriorly, the hind angles distinet not prominent, margin moderate in width and slightly reflexed and with three setigerous punctures, disc convex, shining, sparsely punctured and with but few erect hairs, median line distinctly impressed. Elytra oval, piceous, surface distinetly metallic, humeral spot and lateral margin testaceous, striate, striæ finely punctured, intervals very little convex, irregularly biseriately punctate, the punctures coarser than those of the striæ. Prothorax beneath coarsely punctured at the sides, body and abdomen sparsely punctured or nearly smooth. Length .30-.40 inch: $7.5-10 \mathrm{~mm}$.

Male.-Tarsi as in laticollis. Anal segment feebly emarginate with one seta each side.

Ftmale.-Anal segment entire, bisetose each side.

This species is known among those with wide thoracic margin by the more convex disc of thorax and by the head and thorax paler than the elytra, the latter distinctly metallic in the vast majority of specimens. The humeral spot and pale margin are present in elegans, but this has but one row of interstrial punctures.

Two varieties of this species occur:

Var. brevipennis Zimm.-This is the form containing nineteen in twenty specimens and is that described above.

Var. planipennis Lec. - Of this I have seen but two specimens. The form is essentially the same as the preceding. The color is pale brown with the base of the elytra paler, the surface feebly shining without metallic lustre, the striæ are fine and finely punctured, the intervals flat and indistinctly punctured, the punetures however larger than those of the striæ.

The synonymy of this species has been confused in a way almost impossible to rectify without direct reference to the types. The history is as follows:

The first mention of this species is by Dr. LeConte by whom it was considered cribricollis Dej., (Ann. Lyc. iv, p. 186). In the unpublished manuscripts of Zimmermann, Dr. LeConte found a description of the present species, that author having detected the incorrectness of the reference to cribricollis. Dr. Zimmermann named the species brevipennis, (Trans. Am. Ent. Soc. 1869, p. 243). In the meantime (New Species 1863, p. 6), Dr. LeConte described the form which I consider merely a southern variety under the name planipennis which I retain as the older name. Chaudoir erroneously adopts Kirby's name for the species. 
Occurs from Arizona to New Mexico, Colorado, Utah, Nevada, Oregon and Vancouver, following the distribution of Melanophila miranda and other species.

C. elegans Lec.-Piceous, shining, antennæ and legs pale, elytra with humeral spot and lateral margin paler. Head coarsely and deeply punctured, less closely at the middle of the front. Thorax about one-fifth wider than long, base narrower than the length, sides arcuate in front, very slightly sinuate in front of the posterior angles which are distinct but not prominent, margin moderate in width, searcely reflexed, with two well marked setæ, dise moderately convex, median line distinctly impressed, punctures coarse and deep, sparser at middle, closer at the sides. Elytra regularly oval, a little wider behind the middle, apex not truncate and with very feeble trace of sinuation, surface shining with moderately deep finely punctured striæ, the intervals flat with a single row of punctures coarser than those of the striæ. Prothorax beneath very coarsely and deeply punctate. Metasternum at sides less coarsely punctured. Abdomen nearly smooth. Length .40-.46 inch; $10-11.5 \mathrm{~mm}$.

Sexual characters as in cribricollis.

This is probably one of the most easily recognizable of all the species of the genus. The elytra at tip are more nearly entire than any other and approach the form of some Platynus. The margin of the thorax is less wide than in any of the species which precede but wider than those which follow. It forms in this respect a link between the two series.

Occurs from Massachusetts to Florida and is more common in the southern regions.

C. unicolor Kby.-Form rather slender, piceous, legs and antennæ pale. Head coarsely and moderately densely punctured, nearly equally over the entire surface. Thorax very little wider than long, somewhat cordate, sides arcuate in front, sinuate posteriorly, the hind angles acute and somewhat prominent, narrowly margined, the margin reflexed, and with one setigerous puncture, disc moderately convex, the median line scarcely evident, surface coarsely, moderately densely and equally punctured. Elytra oval slightly broader posteriorly, piceous, moderately shining, without humeral pale space except when immature, dise with finely punctured striæ, the intervals nearly flat, irregularly biseriately punctured. Prosternum coarsely punctured, sides of metasternum and the inflexed margin of the elytra less coarsely punctured. Abdomen sparsely punctured. Length $.34-.36$ inch; $8.5-9 \mathrm{~mm}$.

Male-Anterior tarsi with three dilated joints, biseriately lamellate beneath. Anal segment entire, bisetose each side.

Female.-Tarsi slender. Anal segment entire, bisetose each side.

The abdomen although sparsely is much more closely punctured than in any of the preceding species. 'The thoracic margin is wider than the following species, much less wider than those which precede and not translucent.

Occurs in Labrador, the New England States, Hudson's Bay Territory 
and in Colorado. In the latter region it has been found at an elevation of thirteen thousand feet at Argentine Pass.

C. americana Dej.-Piceous, feebly shining, antennæ, legs, humeral spot and narrow side margin rufo-testaceous. Form rather slender. Head sparsely punctured, especially on the front. Thorax a little longer than wide, narrowed at base, sides narrowly margined, irregularly arcuate in front, sinuate posteriorly, hind angles somewhat obtuse, the margin narrowly reflexed with one setigerous puncture, disc moderately convex, coarsely and equally punctured, median line rather deeply impressed. Elytra oval, broader posteriorly, dise rather flat, with moderately deep finely punctured striæ, the intervals rather flat and densely punctured, the punctures much coarser than those of the striæ, surface subopaque piceous, nearly black, a large humeral spot and narrow side margin rufo-testaceous. Prothorax beneath coarsely punctured, metasternum at sides less coarsely. Abdomen sparsely punctured. Length .44-.64 inch; $11-16 \mathrm{~mm}$.

Male.--Anterior tarsi with three dilated joints, biseriately lamellate beneath. Anal segment emarginate at middle with one seta each side.

Female.-Tarsi slender. Anal segment entire, bisetose each side.

Chaudoir in his essay retains venator distinct from americana basing his determination on two specimens of the former and three of the latter. I believe with Dr. LeConte that the two species are perfectly identical.

Occurs from Canada to the Middle States and Kansas. Chaudoir claims to have seen it from Louisiana but our collections do not contain any from so far south.

C. Cribrata Lec.-Form rather elongate, piceous, antennæ and legs rufotestaceous, elytra with a slightly greenish surface lustre. Head coarsely and deeply punctured, smoother on the front, cribrate above and behind the eyes. Thorax longer than wide, narrowed at base which is strongly arcuate, sides moderately but irregularly arcuate in front, slightly sinuate near the hind angles which are obtuse, margin extremely narrow, disc convex, median line broadly but not deeply sulcate, surface coarsely and rather densely punctured, often cribrate at the sides. Elytra oval, searcely wider behind, with deeply impressed punctured striæ, the intervals convex and with a single irregular row of punctures, margin very narrowly rufous. Prothorax beneath eribrately punctured, metasternum at sides coarsely and densely punctured, abdomen very sparsely punctured. Length .36-.42 inch; $9-10.5 \mathrm{~mm}$.

Male.-Anterior tarsi with three joints dilated and biseriately lamellate beneath. Anal segment entire, bisetose each side.

Female.-Tarsi slender. Anal segment bisetose each side.

This species has some superficial resemblance to borealis but the thorax is more coarsely punctured and the margin extremely narrow. The hairs of the surface are comparatively long and erect, the setæ of the margin of the thorax at least three in number. The elytra are entirely piceous with faint tinge of greenish, the humeri never pale except from immaturity and the lateral margin is very narrowly rufous.

Occurs in western Kansas. 
C. pilosa Say.-Form moderately elongate, piceous, elytra with faint greenish lustre, surface very distinctly pilose. Head coarsely and deeply not densely punctured. Antennæ rufo-testaceous. Thorax about as wide as long, narrower at base, sides arcuate, slightly sinuate posteriorly, narrowly margined, the margin slightly translucent in front and near the hind angles which are rectangular and slightly prominent, disc moderately convex, coarsely and deeply punctured, median line vaguely impressed. Elytra oval scarcely wider behind, with deeply impressed punctured striæ, the intervals slightly convex and rather coarsely, irregularly punctured. Prothorax beneath coarsely and moderately densely punctured, metasternum at sides coarsely and less deeply punctured, the punctures extending also on the inflexed sides of the elytra. Abdomen sparsely punctured. Legs rufo-testaceous. Length .38-.44 inch; $9.5-10 \mathrm{~mm}$.

Sexual characters as in cribrata.

Excepting unicolor the present is the only species in which the thorax is not longer than wide.

This is the common species of the Middle States extending to Canada.

C. borealis Lec.-Form slender, piceous, antennæ and legs pale, elytra with slight greenish lustre with humeral spot and narrow margin pale. Head very sparsely punctate, a little more densely over the eyes. Thorax usually a little longer than wide, narrower at base, sides irregularly arcuate, slightly sinuate in front of the hind angles which are distinct but not prominent, margin narrowly reflexed, dise convex, median line scarcely impressed, surface not densely punctate. Elytra oval not much wider posteriorly, with deeply impressed punctured striæ, the intervals flat, irregularly biseriately punctate. Prothorax beneath and sides of metasternum rather sparsely punetate. Abdomen nearly smooth. Length $.30-.36$ inch; $7 . j-9 \mathrm{~mm}$.

Sexual characters as in cribrata.

Resembles pilosa and cribrata but differs from both in the constant humeral pale space and the more finely and sparsely punctured thorax. It is also more feebly pubescent than either.

\section{Occurs from Nova Scotia to Hudson's Bay Territory.}

C. neglecta Hald.-Form slender, piceous, shining, elytra usually somewhat paler but without distinctly marked humeral spot. Head very sparsely punctate, nearly smooth at middle. Antennæ pale. Thorax distinctly longer than wide, narrower at base, sides moderately arcuate, slightly sinuate posteriorly, hind angles rather obtuse, margin extremely narrow, dise moderately convex, median line rather deeply impressed, surface sparsely and irregularly punctate. Elytra oval, a little wider behind, striæ deep and coarsely punctured, intervals slightly convex with a single row of punctures much finer than those of the striæ. Prothorax beneath coarsely punctured, densely on the sternum, very sparsely at the sides. Metasternum at sides punctured, abdomen nearly smooth. Legs pale. Length $.30-.34$ inch; $7.5-8.5 \mathrm{~mm}$.

Sexual characters as in cribrata.

This species is readily known by its feebly pubescent surface, the rather deep thoracic channel, the very narrow side margin and by the uniseriate punctures of the intervals, very much finer than those of the striæ. 
Chaudoir places unicolor Kby. as a probable synonym of this species. I am inclined to believe from his remarks that the specimens determined by him as neglecta are really borealis, with which Kirby's species might be more aptly compared than the present.

Occurs in the New England and Middle States and is the rarest of our species.

\section{A PEN ES Lec.}

This genus is one of many which have been dismembered from Cymindis from which it differs principally in having the thorax lobed at base. The mouth parts do not differ essentially from Cymindis except that the terminal joint of the labial palpi is more broadly triangular.

With Pinacodera, Apenes is placed by Chaudoir in a group or series which he calls "aberrant Cymindides." The previously indicated group of "true Cymindides" is not defined, consequently it is impossible to determine in what respect these two (with others) are especially aberrant.

Apenes is exclusively an American genus, species occuring from temperate North America to the Argentine Republic.

Those known in our fauna are as follows:

Head longitudinally sulcate.

Surface with a metallic bronze lustre...

lucidula Dej. Head simply punctured.

Elytra shining, striæ distinctly impressed

sinuata Say.

Elytra opaque black, striæ very fine...

opaca Lec.

Head finely strigose or longitudinally wrinkled.

Color brownish, subopaque.

nebulosa Lec.

A. Iucidula Dej.-Form moderately elongate, subdepressed, surface metallic, the head and thorax usually greenish, the elytra dark bronze or cupreous. Head rather deeply longitudinally sulcate. Antennæ rufo-testaceous. Thorax broader than long, narrowed at base, sides areuate, narrowly margined, hind angles distinct but very small, disc feebly convex, the median line entire, surface shining, irregularly wrinkled, at base a few punctures, at apex longitudinally strigose. Elytra with a pale humeral spot (sometimes absent) at the base of the sixth interval, surface with moderately deeply impressed, finely punctured striæ, the intervals slightly convex, finely alutaceous and obsoletely sparsely punctulate, dorsal punctures two, the anterior at the middle of the elytra equidistant from the second and third striæ, the posterior near the second stria. Body beneath piceous, shining, nearly smooth, tibiæ and tarsi paler. Length .40 inch; $10 \mathrm{~mm}$.

Male.-The anterior tarsi have four joints dilated and biseriately lamellate beneath, the middle tarsi narrowly dilated not lamellate. The anal segment has one puncture each side.

Femule.-Tarsi slender. Anal segment with two punctures.

Variations of the color of the surface are often observed. The legs 
are usually piceous, sometimes testaceous. A. angustata Schz. is merely a narrower race of bright surface color, similar forms are found by Mr. Ulke near Washington.

Occurs from New York to Florida.

A. sinuata Say.-Piceous, moderately shining, without metallic lustre. Head sparsely punctate, a few wrinkles at side of front. Antennæ rufo-testaceous. Thorax about one-third wider than long, sides moderately arcuate, very slightly sinuate in front of the basal angles which are distinct but not prominent, margin extremely narrowly reflexed, dise moderately convex, median line entire, subapical line feeble, surface shining, sparsely punctate, more densely near the apex. Elytra oblong-oval, surface with distinctly impressed, finely punctured striæ, the intervals slightly convex, very finely alutaceous, the dorsal punctures on the third interval nearer the second stria, the anterior in front of middle, color piceous with a pale humeral space and a subapical testaceous fascia. Body beneath piceous, prosternum at middle and metasternum at sides sparsely punetate. Legs testaceous. Length .28 inch; $7 \mathrm{~mm}$.

Sexual characters as in lucidula.

The elytra have at the humerus a pale testaceous space which begins on the fifth interval and reaches the side, extending one-third the length of the elytra and along the extreme margin to the middle. The subapical fascia is sinuous and does not reach the side margin nor the suture.

Occurs from the Middle States to Texas.

A. Opaca Lec.-Piceous, head and thorax shining, elytra opaque black. Head very sparsely punctulate, a few wrinkles in front of the eyes. Antennæ rufo-testaceous, a little longer than the head and thorax. Thorax one-third wider than long, distinetly narrowed at base, sides arcuate, slightly sinuous in front of the hind angles which are slightly prominent, dise very slightly convex, surface sparsely finely punctulate, a few wrinkles along the sides and apex, median line entire. Elytra elongate-oval, rather flat, striæ fine and with minute punctures, intervals very flat, dorsal punctures as in sinuata but very indistinct; color opaque black with a faint triangular paler humeral spot. Body beneath piceous, smooth. prosternum scarcely visibly punctulate. Legs testaceous. Length .30 inch; $7.5 \mathrm{~mm}$.

Sexual characters as in lucidula.

This species appears more closely allied to morio and parallela than to any in our fauna.

Occurs in Georgia and Florida, and appears to be rare as I have seen but three specimens.

In the Bull. Mosc. 1875, Baron Chaudoir reviews the species of this genus and describes a new one as $A$. opaca from the Argentine Republic. A new name should be given it by any one knowing the species, the practice of changing the preoccupied names of unknown species is by no means a good one and generally results in no good to science. 
A. nebulosa Lee. - Brownish piceous, subopaque. Head strigose and sparsely punctulate, darker in color. Antennæ brownish testaceous. Thorax nearly twice as wide as long, narrower at base, sides moderately arcuate, a slight sinuation near the hind angles which are distinct but not prominent, disc slightly convex, median line distinetly impressed, surface finely strigose and very sparsely punctulate. Elytra oblong-oval, the striæ distinetly impressed and obsoletely punctulate, intervals very slightly convex and finely alutaceous; color brownish piceous with a paler humeral space and subapical fascia, as in sinuata. Body beneath smooth, legs testaceous. Length .24 inch; $6 \mathrm{~mm}$.

Sexual characters as in lucidula.

This species having paler elytra than sinuata, the humeral spot and subapical fascia do not show as plainly as in that. The subapical fascia is, however, more nearly complete and posterior to the humeral spot there is sometimes an additional paler mark on the fifth interval.

Occurs in Arizona extending to Cape San Lucas, Lower California.

EUCARUS Lec.

Mentum transverse, rapidly narrowing to the front, at middle rather deeply emarginate without tooth, epilobes distinct, their apices acute. Basal membrane of the ligula nearly filling the emargination. Ligula (proper) small, the apex dilated, truncate and bisetose, paraglossæ rather broad adherent to the ligula and slightly prolonged beyond it. Labial palpi moderate in length, the terminal joint fusiform, the tip membranous and subulate, the surface pubescent, the penultimate joint bisetose in front. Maxillæ slender, the inner lobe acute at tip and with an acute tooth behind the tip, inner edge eiliate beginning a short distance behind the tooth; outer lobe slender the terminal joint a little shorter. Maxillary palpi moderate in length, the terminal joint as in the labial palpi. Mandibles not prominent, acute at tip, scrobe well marked. Labrum moderately prominent, quadrate, slightly transverse, the angles obtuse, quadrisetose in front. Antennæ with the pubescence covering the third joint and extending slightly on the second.

I have dwelt in some detail on the mouth parts as these have not heretofore been fully described. A figure of the mentum, ligula and maxilla will be found in the preceding volume of these Transactions, pl. viii, fig. 100 .

E. varicornis Lec. - This is the only species in our fauna. It is a small insect (.12-.14 inch; $3-3.5 \mathrm{~mm}$.) piceous in color with the elytra somewhat iridescent, head darker, legs testaceous, antennæ piceous the outer five joints nearly white. A figure in outline will be found in Transactions vol. ix, pl. iv, fig. 5 .

Occurs in the southeastern Gulf States, and very rare.

PENTA GONICA Schmidt-Goebel.

The name above given has been adopted by Chaudoir and others, for what reason I am unable to state, as the name Rhombodera Reiche, appears with date $184^{\circ}$, four years anterior to Pentayonica.

The details of structure have already been sufficiently given by Lacordaire, (Genera i, p. 133), and need no further reference here except as to the form of the mandibles, which are more explanate 
than usual in the present tribe and without the usual excavation on the outer side.

One species occurs in our fauna.

P. flavipes Lec. - A small species with a general resemblance to some of the varieties of Lebia analis. The thorax is short the sides strongly angulate, the base narrowed. The elytra are very vaguely striate without punctures, the surface finely alutaceous. The legs are always testaceous, the under surface of the body piceous, except the prothorax. Length .14-.18 inch; $3.5-4.5 \mathrm{~mm}$.

Male.-The anterior tarsus is feebly dilated, the first joint somewhat spinous beneath, the second and third with a few squamules biseriately placed. The middle tarsus is not at all dilated. The anal segment has one seta each side.

Female.-Tarsi slender. Anal segment bisetose each side.

This species varies greatly in color and forms three varieties.

Var. flavipes Lec.-Entirely piceous. Legs testaceous.

Var. bicolor Lec.-Head and thorax above and beneath pale reddish-yellow. Legs testaceous.

Var. — - - Head piceous, thorax reddish-yellow, elytra piceous. Legs testaceous.

Although very rare the species has a wide distribution, occuring in the Gulf States, extending northward to Illinois and Kansas and westward to Arizona.

\section{ONO'TA Chaud.}

Mentum emarginate, without tooth, the epilobes slightly prominent; ligula corneous, truncate in front, apex a little narrowed and bisetose; paraglossæ membranous prolonged beyond the ligula and extending narrowly across its apex; palpi moderate, terminal joint elongate-ovate. Labrum in front feebly emarginate, sexsetose, base narrower. Mandibles expanded, laminiform, without scrobe. Maxillary palpi moderate, terminal joint as in the labial. Antennæ with the first three joints and the base of the fourth glabrous. Head gradually narrowed behind the eyes to the neck. Thorax angulate at the sides, base truncate at middle, on each side slightly oblique. Elytra with two dorsal punctures, situated on the third interval close to the second stria. Tarsi flattened and subsulcate above, fourth joint bilobed. First joint of posterior tarsi as long as the three following. Ungues pectinate.

This genus is placed by Chaudoir in his Callidides, which seems as convenient a position as any, taking the ligula as a key to classification. This organ has had an exaggerated importance given it by many late authors, and even with our limited number of genera I have found it impossible to separate the truncatipenne series in smaller groups. In my table of the genera of the tribe Lebiini, (Trans. Amer. Ent. Soc. ix, p. 156), I have placed Eucærus, Pentagonica, (Rhombodera) and Ousta in close approximation, indicating thereby a relationship between them, while it must at the same time be admitted that each has other relationship about as well marked-Pentagonica with Lebia, Onota with Callida, and Eucærus with Ega. 
Onota is represented in our fauna by one species.

D. Floridana Horn.-Reddish testaceous, elytra bluish-green, striate. Length $.20-.25$ inch; $5-6 \mathrm{~mm}$.

Male.-Anterior tarsi feebly dilated, the first three joints biseriately lamellatepapillose beneath, fourth joint hairy. Middle tarsi without papillæ. Anal segment with one seta each side.

Female.-Tarsi less dilated, not papillose. Anal segment bisetose each side.

Occurs near Lake Poinsett, Fla.; concealed in the leaves of Palmetto.

\section{Bibliography and Synonymy.}

\section{TETRAGONODERUS Dej.}

T. intersectus Germ. (Bemb.) Ins. Spec. nov. p. 28.

Lecontei Dej. Species iv, p. 449.

distigma Motsch. Bull. Mose. 1864, ii, p. 222.

T. fasciatus Hald. Proc. Acad. i, p. 298; Lec. (Thyreop.) Ann. Lyc. iv, p. 197. undulutus Lec. New Species 1863, p. 7.

T. latipennis Lec. Trans. Am. Ent. Soc. 1874, p. 44.

T. pallidus Horn, Trans. Am. Ent. Soc. 1868, p. 130.

\section{NEMOTARSUS Lec.}

N. elegans Lec. Trans. Amer. Philos. Soc. 1853, p. 377 ; Chaud. Bull. Mosc. 1876; Horn, Trans. Am. Ent. Soc. ix, pl. iv, fig. 2.

\section{COPTODERA Dej.}

C. ærata Dej. Species i, p. 277; Chaud. Annales Belg. 1869, p. 179. viridipennis Gory, Annales France, 1833, p. 194. viridipennis Lec. Ann. Lyc. iv, p. 196. ruficornis Chaud. loc. cit. p. 179.

\section{PHLEOXENA Chaud.}

P. signata Dej. (Coptodera) Species i, p. 275 ; Chaud. Ann. Belg. 1869, p. 151. collaris Lec. (Coptodera) Ann. Lyc. iv, p. 197.

\section{DROMIUS Bon.}

D. piceus Dej. (Cymindis) Species v, p. 353. quadricollis Lec. Proc. Acad. 1859, p. 82.

D. atriceps Lec. Trans. Am. Ent. Soc. viii, p. 163.

\section{APRISTUS Chaud.}

A. cordicollis Lec. (Dromius) Ann. Lyc. iv, p. 190.

A. subsulcatus Dej. (Dromius) Species ii, p. 451. latens Lec. Ann. Lyc. iv, p. 191. fuscipennis Motsch. Bull. Mosc. 1864, iii, p. 233.

A. laticollis Lec. Ann. Lyc. v, p. 176.

\section{BLECHRUS Motsch.}

B. nigrinus Mann. (Dromius) Bull. Mose. 1843, ii, p. 184. angustus $\|$ Lec. (Dromus) Ann. Lyc. iv, p. 191. linearis Lee. (Bomius) Ann. Lye. v. p. 177. 
B. lucidus Lec. (Bomius) Ann. Lyc. v, p. 177.

B. pusio Lec. New Species 1863, p. 6.

METABLETUS Schmidt-Goebel.

M. americanus Dej. (Dromius) Species v, p. 361.

borealis Zimm. Trans. Am. Ent. Soc. 1869, p. 243.

AXINOPALPUS Lec.

A. biplagiatus Dej. (Dromius) Species i, p. 243. californicus Motsch. Bull. Mose. 1845, iv, p. 356, pl. v, fig. 1.

A. fusciceps Lec. Ann. Lyc. v, p. 175.

nigriceps Lec. Trans. Am. Ent. Soc. 1880, p. 164.

TECNOPHILUS Chaud.

T. croceicollis Ménét. (Callida) Bull. Ac. Petr. ii, 1844, p. 53. chloridipennis Motsch. Käf. Russl. 1850, p. 39, note 3. ruficollis Lec. Ann. Lyc. v, 1851, p. 176. nigricollis Lee. loc. cit.

Pilatei Chaud. Bull. Mosc. 1877, i, p. 239.

glabripennis Chaud. loc. cit. p. 242, note.

\section{EUPROCTUS Solier.}

Eu. trivittatus Lec. (Onota) Proc. Amer. Philos. Soc. 1878, p. 373 ; Horn, Trans. Am. Ent. Soc. ix, pl. iv, fig. 3.

\section{CALLIDA Dej.}

C. platynoides Horn, n. sp.

C. planulata Lec. Proc. Acad. 1858, p. 59.

C. viridipennis Say, (Cymindis) Trans. Amer. Philos. Soc. 1823, vol. ii, p. 9; Lec. Ann. Lyc. iv, p. 189; Chaud. Ann. Belg. 1872, p. 117. marginata Dej. Spec. i, p. 222.

C. decora Fab. (Carabus) Syst. El. i, p. 181; Dej. Spec. i, p. 224; Icon. Col. ed. 1, v. ii, pl. vii, fig. 7 ; Chev. Col. Mex. fasc. ii, n. 36 . cordicollis Putz. Mem. Liege ii, p. 373. cyanoptera Lec. Proc. Acad. 1858, p. 59.

C. punctata Lec. Ann. Lyc. iv, p. 189; Chaud. (Spongoloba) Ann. Belg. 1872, p. 152.

C. fulgida Dej. Species v, p. 330; Chaud. (Spongoloba) loc. cit.

C. purpurea Say, (Cymindis) Trans. Amer. Philos. Soc. 1823, p. 10. smaragdina Dej. Species i, p. 225 ; Chaud. (Spongoloba) loc. cit. cyanipennis Chaud. Bull. Mose. 1844, p. 467.

PHILOPHUGA Motsch.

P. viridicollis Lec. (Cymindis) Ann. Lyc. iv, p. 188. purpurea $\ddagger$ Chd. (nec Say,) Bull. Mose. 1877, i, p. 245.

P. amœna Lec. (Cymindis) Ann. Lyc. iv, p. 188. purpurea ‡ Lec. (nec Say,) loc. cit. Horni Chd. Bull. Mosc. 1877, i, p. 245.

P. viridis Dej. (Cymindis) Spec. v, p. 325 ; Chd. Bull. Mose. 1877, i, p. 244. cyanea Motsch. Käf. Russl. 1850, p. 39, n. 4; Bull. Mosc. 1859, iii, p. 143, pl. iii, fig. 5 .

P. castanea Horn, n. sp.*

* In addition to the above list Chaudoir describes P. subcordata from Mexico which does not seem distinct from viridicallis Lec.

TRANS. AMER. ENT. SOC. $X$.

SEPTEMBER, 1882 . 


\section{PLOCHIONUS Dej.}

P. pallens Fab. Syst. El. i, p. 244 ; Chaud. Ann. Belg. 1872, p. 168. Bonfilsi Dej. Spec. i, p. 251; Hope, Col. Man. ii, pl. i, fig. 6. Boisduvali Gory, Ann. Fr. 1833, p. 189. valens Lec. New Species, 1863, p. 5.

P. timidus Hald. Proc. Acad. i, p. 298.

P. amandus Newm. Entomol. i, p. 32 . vittatus Lec. Proc. Acad. ii, p. 48.

P. dorsalis Horn, n. sp.

\section{PINACODERA Schaum.}

P. limbata Dej. (Cymindis) Species v, p. 320.

v. fuscata Dej. idem. p. 321.

lovigatus Motsch. (Planesus) Bull. Mosc. 1864, ii, p. 297.

fuscicollis Motsch. idem. p. 298.

P. platicollis Say, (Cymindis) Trans. Amer. Philos. Soc. ii, p. 14. camplanata Dej. (Cymindis) Species ii, p. 448.

russata Newm. (Lebia) Entom. p. 31.

P. punctigera Lec. (Cymindis) Ann. Lyc. v, p. 178.

P. semisulcata Horn, n. sp.

P. sulcipennis Horn, n. sp.

CYMINDIS Latr.

C. laticollis Say, Trans. Amer. Philos. Soc. iv, p. 413 ; Lec. Ann. Lyc. iv, p. 186 ; Chaud. Berl. Zeitsch. 1873, p. 95. villigera Chaud. loc. eit. p. 96.

C. cribricollis Dej. Species v, p. 311 ; Chaud. loc. cit. p. 97. marginata Kby. Fauna Bor. Am. iv, Ins. p. 13. reflexa Lec. Agass. Lake Sup. p. 203. abstrusa Lec. Proc. Acad. 1859, p. 82.

c. planipennis Lec. New Species 1863, p. 6. cribricollis $\ddagger$ Lee. Ann. Lyc. iv, p. 186.

brevipennis Zimm. Trans. Am. Ent. Soc. 1869, p. 243. marginata $\ddagger$ Chaud. Berl. Zeitsch. 1873, p. 96.

C. elegans Lec. Ann. Lyc. iv, p. 186.

C. unicolor Kby. Fauna Bor. Am. iv, p. 14. hudsonica Lec. New Species, 1863, p. 6; Proc. Acad. 1873, p. 322.

C. americana Dej. Species ii, p. 446 ; Chaud. Berl. Zeitsch. 1873, p. 102. venator Dej. Species v, p. 311; Chaud. loc. cit. p. 103.

C. cribrata Lec. Col. Kansas, 1859, p. 2.

C. pilosa Say, Trans. Amer. Philos. Soc. ii, p. 10. pubescens Dej. Species i, p. 215.

C. borealis Lec. New Species 1863 , p. 7.

C. neglecta Hald. Proc. Acad. i, p. 298.

\section{APENES Lec.}

A. lucidula Dej. (Cymindis) Species v, p. 320. var. angustata Schwarz, Proc. Amer. Philos. Soc. 1878, p. 354.

A. sinuata Say, (Cymindis) Trans. Amer. Philos. Soc. ii, p. 8. pustulata Dej. Species v, p. 316.

A. opaca Lee. Ann. Lyc. v, p. 175 .

A. nebulosa Lec. Proc. Acad. Nat. Sc. 1866 , p. 364 . 


\section{EUC压US Lec.}

E. varicornis Lec. Trans. Amer. Philos. Soc. 1853, p. 387.

PENTAGONICA Schmidt-Goebel.

P. flavipes Lec. (Didetus) Trans. Amer. Philos. Soc. 1853, p. 377.

bicolor Lec. (Rhombodera) New Species 1863, p. 7.

americana Motsch. Bull. Mose. 1864, iii, p. 224.

P. angulata Boh. (Lebia) Eugen. Resa p. 7, is probably from South America. The name goniodera proposed by Harold is unnecessary.

ONOTA Chaud.

0. Floridana Horn, Trans. Am. Ent. Soc. ix, p. 157, pl. iv, fig. 4.

\section{EXPLANATION OF PLATE IV.}

Fig. 1. Elytral markings of Melanophila miranda Lec.

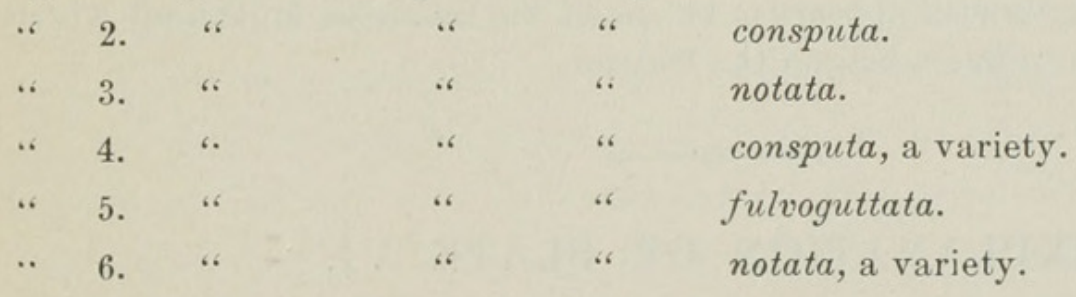

“. 7. Xenorhipis Brendeli Lec. $\delta$.

" 8. " " . .

“ 9. Antenna of 7 , more enlarged.

. 10. Moncedus guttatus Lec.

. 11. Dasycerus carolinensis Horn.

“ 12.4 angulicollis Horn.

“ 13. Mouth parts of Aphonus tridentatus Say. 


\section{$2 \mathrm{BHL}$ Biodiversity Heritage Library}

1882. "Synopsis of the species of the tribe Lebiini." Transactions of the American Entomological Society and proceedings of the Entomological Section of the Academy of Natural Sciences 10, 126-163.

View This Item Online: https://www.biodiversitylibrary.org/item/32792

Permalink: https://www.biodiversitylibrary.org/partpdf/70448

\section{Holding Institution}

Smithsonian Libraries

\section{Sponsored by}

Smithsonian

\section{Copyright \& Reuse}

Copyright Status: NOT_IN_COPYRIGHT

This document was created from content at the Biodiversity Heritage Library, the world's largest open access digital library for biodiversity literature and archives. Visit BHL at https://www.biodiversitylibrary.org. 